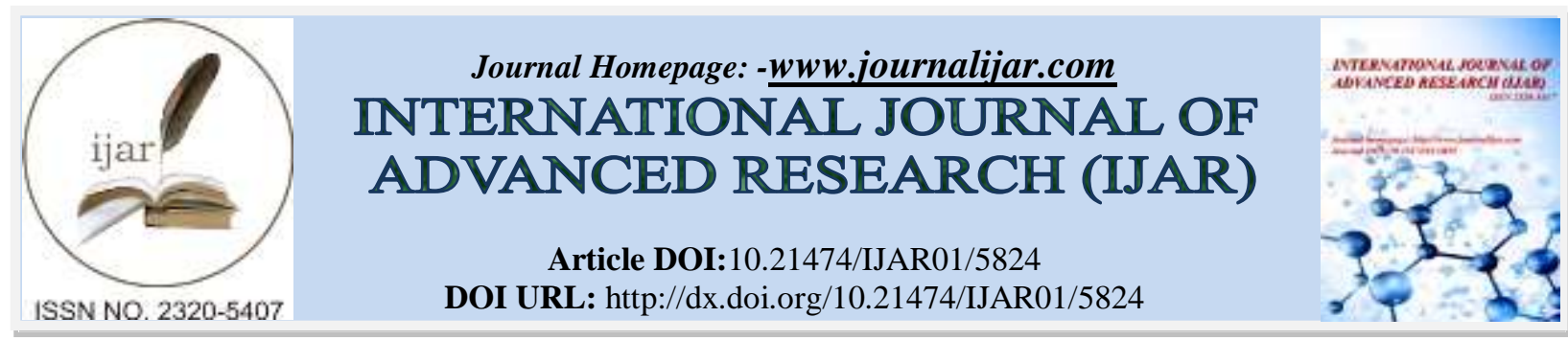

RESEARCH ARTICLE

\title{
A NEW REMARKABLE SPECIES OF DIMERIA R. Br. (POACEAE, PANICOIDEAE, ANDROPOGONEAE) FROM THE LATERITIC PLATEAUS OF NORTHERN KERALA, INDIA.
}

\author{
${ }^{*}$ P. Biju ${ }^{1,3}$, E. J. Josekutty ${ }^{2,3}$ and JomyAugustine ${ }^{3}$.
}

1. Department of Botany, Government College, Kasaragod, Vidyanagar P.O., Kasaragod - 671123, Kerala, India.

2. Department of Botany, Government Brennan College Thalassery, Dharmadam P.O., Kannur - 670106, Kerala, India.

3. Department of Botany, St. Thomas College, Pala, Arunapuram P.O, Pala - 686574, Kerala, India.

\section{Manuscript Info}

(........................

Manuscript History

Received: 10 September 2017

Final Accepted: 12 October 2017

Published: November 2017

Key words:-

Endemic species,Dimeriinae, Kalliyad,

Dimeriakalliadense.

\section{Abstract}

A new species Dimeria kalliadense, collected from the lateritic plateau of Northern Kerala, India is described and illustrated. This new species is similar to Dimeria keralae in having intertwining racemes, oblique tip of the pedicel, long callus and callus hairs, upper glumes with round and echinate dorsal surface, but differs in having two sub-equal racemes, long pedicel, larger and distantly arranged spikelets, aristate upper glumes, acuminate lower glume, very long and hairy column of awns, lower lemma with dorsal keel and larger vinaceous anthers.

Copy Right, IJAR, 2017, All rights reserved.

\section{Introduction:-}

The genus Dimeria R. Br. belongs to the subtribe Dimeriinae, tribe Andropogoneae, supertribe Panicodae, and subfamily Panicoideae of the family Poaceae (Soreng et al., 2015). But Kellogg (2015) placed the genus Dimeria in the subtribe Ischaeminae along with Andropterum Stapf and Ischaemum L. Kiran Raj et al. (2013) described a new monospecific genus Nanooravia in the Subtribe Dimeriinae based on his studies on Dimeria santapaui and Dimeria keralae. The studies of Kellogg (2015) revealed that the segregation of the new genus Nanooravia is premature and hence retained in the genus Dimeria. Based on the rachis characters, Bor (1952) classified the genus Dimeria R. Br. in to three sections: Capillares, loriformes and Annulares. Kiran Raj et al. (2015) proposed a new section Dimeria with eleven species. The species Dimeria keralae and Dimeria santapaui were not included in any of the four section of Dimeria, as they were separated in to a new genus Nanooravia. (Kiran Raj et al., 2013). These two species possess slender rachis with distantly arranged spikelets with long pedicels. Hence they belong to the section Capillares. The genus can be easily distinguished by solitary, laterally compressed spikelets and flat or filiform rachis without joints (Sreekumar et al., 1991). The genus Dimeria R.Br. is represented by 59 species (Mabberley, 2017) in the world. The genus shows greatest diversity in the peninsular India with 40 species. (Kiran Raj et al., 2008). Recently a new species (Gosavi et al., 2016) and a new subspecies (Kran Raj et al., 2016) were described from India.

During the floristic explorations in the lateritic plateaus of Northern Kerala, India, the authors collected a very interesting specimen of Dimeria R. Br. with characteristically long and hairy awns. The detailed study of the specimen revealed that the new specimen differ distinctly from all other species Dimeria R. Br. reported so far. Hence it is described here as a new species. 


\section{Taxonomy:-}

Dimeria kalliyadense Biju, Josekutty \& Augustine J. sp. nov. Fig. $1 \& 2$.

Type:-India: Kerala: Kannur District, Kalliyad lateritic plateau, N 1200'46.8", E 075³4'06", 190 m, 14 September 2013, Biju\&Jomy 2468 (holotype: CAL, isotype: MH).

\section{Diagnosis:-}

Dimeria kalliadense resembles Dimeria keralae in having spirally twisted racemes, round and echinate dorsal surface of the upper glumes, distantly arranged spikelets, pedicels with extremely oblique tip, upper lemma with stout and long awns; but differs in having two sub-equal racemes, long pedicel, larger spikelets, aristate upper glumes, acuminate lower glumes, long and hairy column of the awns, dorsally keeled lower lemma and larger vinaceous anthers.

\section{Description:-}

Erect marshy-terrestrial annuals, up to $70 \mathrm{~cm}$ high; culms solitary or 2-4 together. Nodes sparsely hairy or glabrous; upper nodes slightly geniculate. Leaves few to many, crowded at the base; leaf blade linear-lanceolate, 5-7 $\times 0.2-$ $0.5 \mathrm{~cm}$, acuminate at apex, round at base, covered with long bulbous based hairs on both surface; hairs up to $3.5-4.2$ mm long; margins with bulbous based hairs and spinulate towards the apex. Ligules membranous, up to $0.5 \mathrm{~mm}$ broad, ciliate at the apex. Leaf sheath $3.5-4.8 \mathrm{~cm}$ long, shorter than the internodes, distinctly keeled, thinly hairy above. Racemes 2, sub-equal, intertwined when dry, 8.0-10.5 cm long; rachis 0.5-0.6 mm wide, trigonous, glabrous. Spikelets solitary, oblong, laterally compressed, straw colored, greenish tinct at apex, 8-11 $\times 0.5-0.8 \mathrm{~mm}$, 5.0-9.2 mm apart, ca. 8 spikelets in each rachis. Pedicels $1.8-2.5 \mathrm{~mm}$ long, glabrous, rarely bearded at the base, extremely oblique at apex; callus 2-2.3 mm long, covered by golden hairs; hairs 2.0-2.5 mm long. Lower glumes 4.5-5.3 × 0.3-0.4 mm, linear-lanceolate, laterally compressed, acuminate, echinate on the back towards apex, convex and dark outside, concave and hyaline inside; margins hyaline and narrowly winged; nerves obscure. Upper glume 7.5-9 × 0.7-0.8 mm, crustaceous, elliptic-lanceolate, aristate with few long bristles at apex, rounded on back; margins hyaline and narrowly winged towards the apex, nerves obscure. Florets 2 . Lower floret empty and reduced to lemma only, lemma 4-5 × 0.4-0.5 mm, oblanceolate-elliptic, membranous, hyaline, acuminate, distinctly keeled; keel $0.25 \mathrm{~mm}$, ciliate; nerve one, distinct. Upper floret bisexual; upper lemma 4.5-5.0 $\times 0.7-0.8 \mathrm{~mm}$, membranous, oblong, faintly one nerved, incised at the apex, awned; awn arises from the cleft at the apex, 5.0-6.2 cm long; column 3-3.5 cm long, grooved with long hairs on both sides; paleaoblanceolate, $0.6-0.7 \times 0.1-0.2 \mathrm{~mm}$, membranous, ciliate along the margins and dorsal side towards the apex;nerves obscure; lodicules trilobed, $0.2-0.25$ $\mathrm{mm}$ across, hyaline, glabrous; stamens two, free; filaments up to $1 \mathrm{~mm}$ long; anthers oblong, vinaceous, $2.5-3 \times$ $0.2-0.3 \mathrm{~mm}$; ovary elliptic-ovoid, $0.4-0.5 \times 0.15-0.2 \mathrm{~mm}$, glabrous; styles 2, 2.0-2.8 mm long; stigmas $1.5-2.0$ $\mathrm{mm}$, feathery. Grain 3-3.5 × 0.3-0.4 mm, oblong-elliptic, yellowish brown.

\section{Flowering \& Fruiting:-}

August-January.

\section{Etymology:-}

The new species is named after the type locality, Kalliyad, Kerala, India.

\section{Additional specimen examined:-}

India, Kerala, Kasaragod District, Seethamgoli lateritic plateau, N 12²6'44.8", E 07500'23.6", 102 m., 10 september 2015, Biju \& Jomy 2515; India, Kerala, Kasaragod District, Karindalam lateritic plateau, N 12¹9'35.1", E 075¹4'59.3", 187 m, 22 0ctober 2016, Biju \& Jomy 2730; India, Kerala, Kannur District , Peringome lateritic plateau, N 12 $04^{\prime} 06.7^{\prime \prime}$ E 075³6'83.9", 86 m, 25 october 2016, Biju \& Jomy 2740, Kanayi lateritic plateau, N 12 08'37.1", E $075^{\circ} 14^{\prime} 46.1^{\prime \prime}, 86$ m, 26 october 2016, Biju \& Jomy 2742 (St. Thomas College Herbarium, Pala, Kerala, India).

\section{Ecology:-}

Dimeria kalliadense grows in association with Rhynchospora wightiana (Nees) Steud (Steudel, 1855), Rhamphicarpa fistulosa (Hochst.) Benth (Bentham, 1846), Centranthera indica (L.) Gamble (Gamble, 1924) and Dimeria thwaitesii Hack (Hackel, 1889). It shows spiral twisting of two racemes and awns during dry conditions and regains the original condition when wet. The spikelets shows an oval thin depression at the base of upper glumes, which is densely covered by long callus hairs. The thin oval region changes into an opening in the fallen spikelets. 
The rain water trapped by the callus hairs enters spikelets through the opening and ensures successful seed germination.

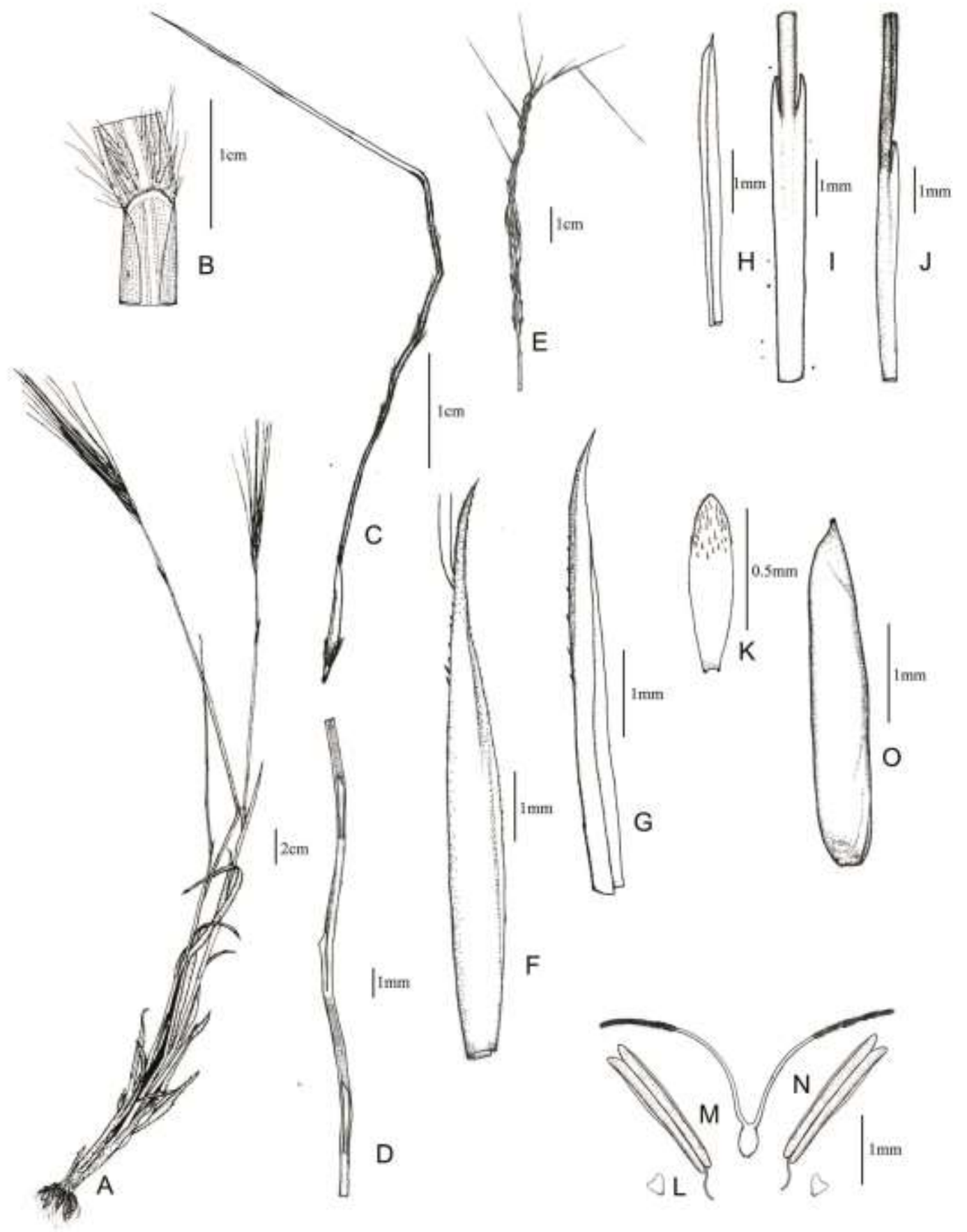

Figure 1:- Dimeria kalliadense (A) Habit. (B) Ligule. (C) Spikelet. (D) Rachis. (E) Spirally twisted racemes. (F) Upper glume. (G) Lower glume. (H) Lower lemma. (I) Upper lemma dorsal view. (J) Upper glume lateral view. (K) Palea. (L) Lodicule. (M) Stamen. (N) Pistil. (O) Caryopsis. 


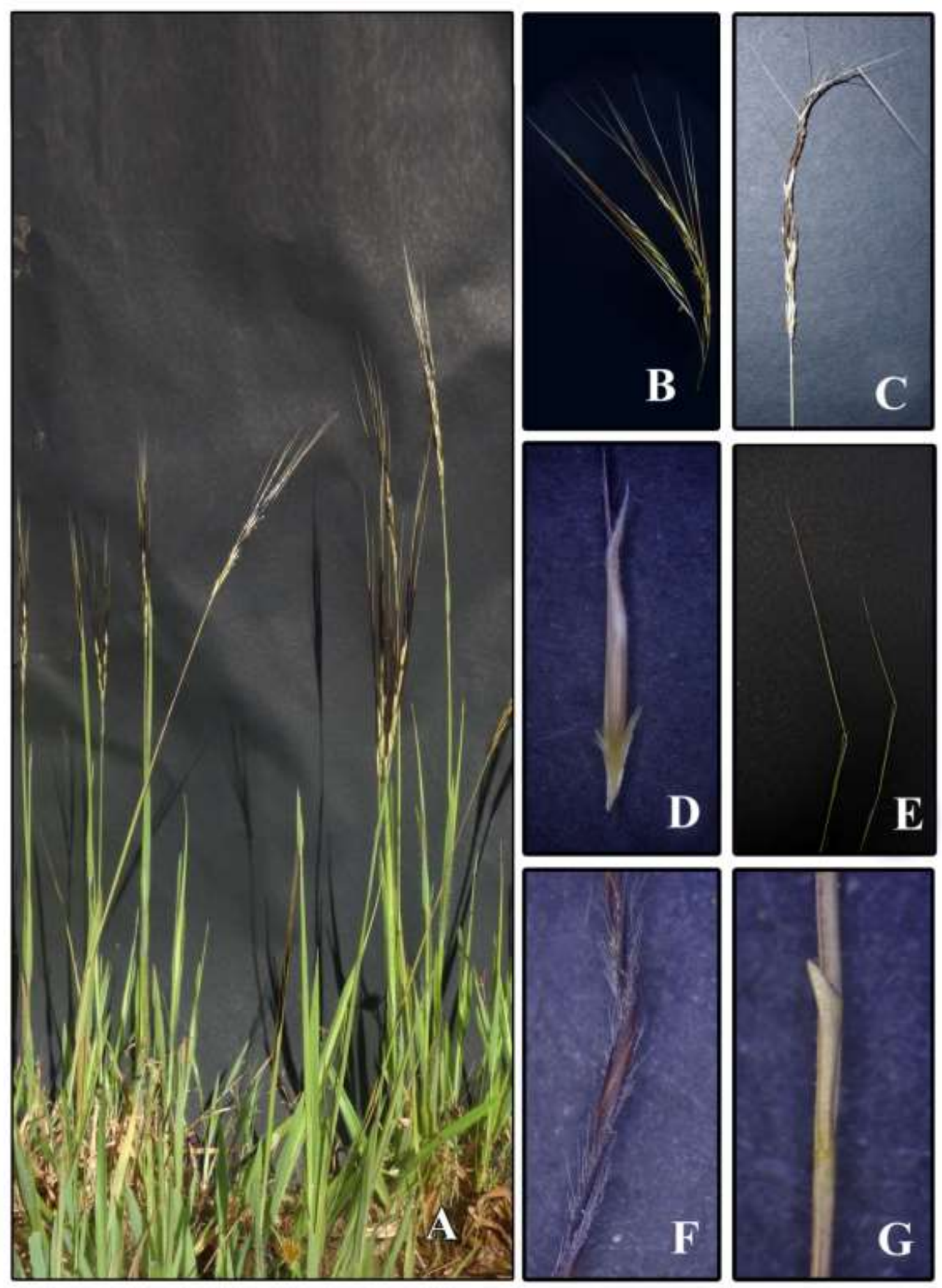

Figure 2:- Dimeria kalliadense (A) Habit. (B) Inflorescence. (C) Spirally twisted racemes. (D) A portion of the spikelet (E) Bending of stem at maturity. (F) Hairy column of the awn (G) A portion of the rachis. 


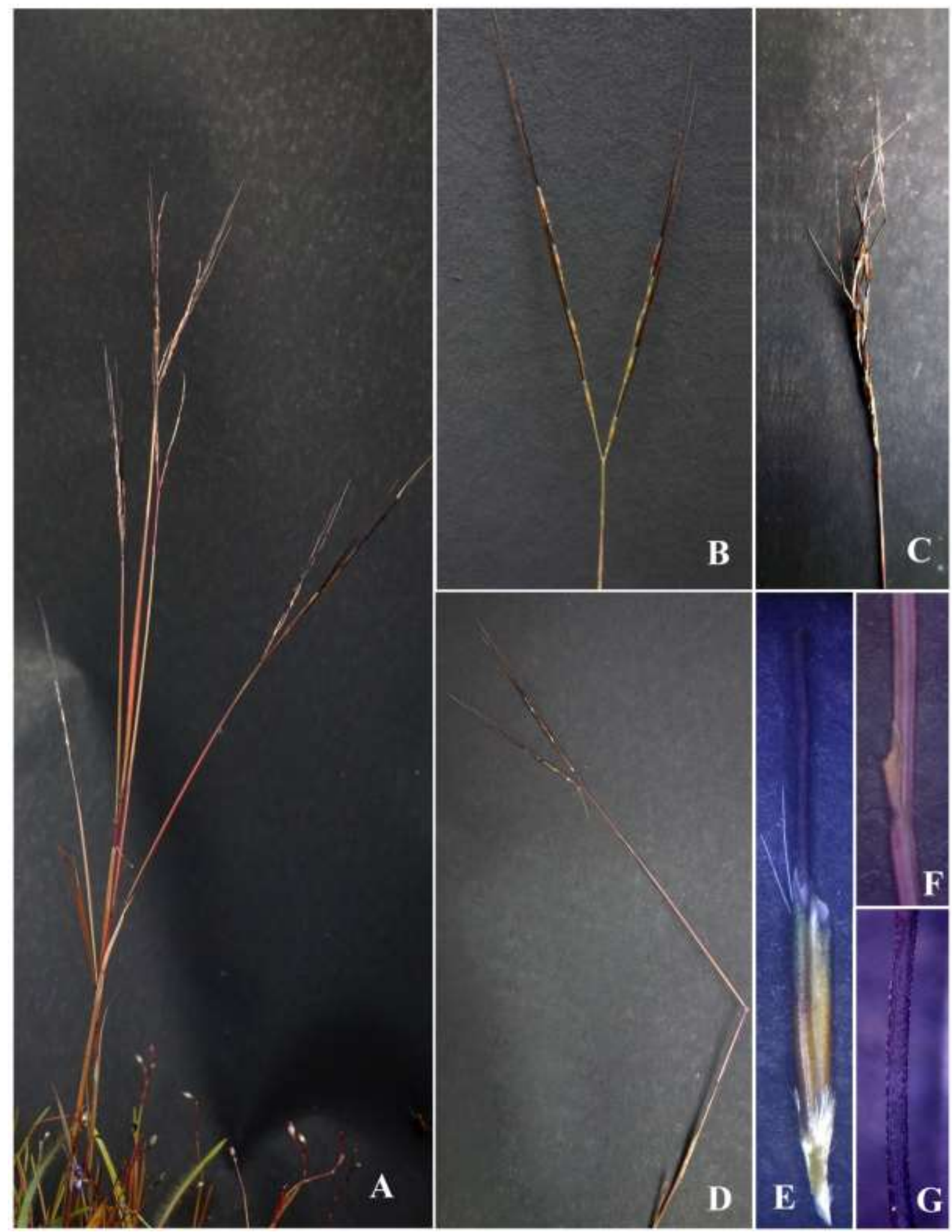

Figure 3:- Dimeria keralae (A) Habit. (B) Inflorescence. (C) Spirally twisted racemes. (D) Bending of stem at maturity. (E) A portion of the spikelet. (F) A portion of the rachis. (G) Column of the awn. 


\section{Similar species:-}

Dimeria kalliadense is closely allied to Dimeria keralae (Figure 3.), but differs in several characters (Table 1.). It is also allied to Dimeria santapaui and Dimeria blatteri, but differs in the number of racemes, long callus, aristate upper glumes, acuminate lower glumes, long and hairy column of the awns, dorsally keeled lower lemma and larger vinaceous anthers.

Table 1:- Comparison of characters of Dimeria kalliadense and Dimeria keralae

\begin{tabular}{|c|c|c|}
\hline Character & Dimeria kalliadense & Dimeria keralae \\
\hline Habit & Plants up to $70 \mathrm{~cm}$ tall & Plants up to $30 \mathrm{~cm}$ tall \\
\hline Node & Sparsely hairy or glabrous & bearded \\
\hline Leaf & $\begin{array}{l}\text { Lamina linear-lanceolate, not distinctly keeled } \\
\text { on the midrib below, covered by long hairs on } \\
\text { both sides. Leaf sheath sparsely hairy towards } \\
\text { tip. Ligules } 0.5 \mathrm{~mm} \text { long with ciliate apex. }\end{array}$ & $\begin{array}{l}\text { Lamina linear-subulate, distinctly keeled on the } \\
\text { midrib below, glabrous. Leaf sheaths glabrous. } \\
\text { Ligules } 1 \mathrm{~mm} \text { long with fimbriate apex. }\end{array}$ \\
\hline Pedicel & $\begin{array}{l}1.8-2.5 \mathrm{~mm} \text { long with sharp oblique tips. } \\
\text { Rarely bearded at the base of pedicel. }\end{array}$ & $\begin{array}{l}1.0-1.5 \mathrm{~mm} \text { long with oblique-concave tips. } \\
\text { Pedicel base not bearded. }\end{array}$ \\
\hline spikelet & $\begin{array}{l}8-11 \mathrm{~mm} \text { long, straw colored with greenish } \\
\text { tips. }\end{array}$ & 5-6 mm long, brownish colored. \\
\hline Callus & $2.0-2.3 \mathrm{~mm}$ long, hairs up to $2.5 \mathrm{~mm}$ long. & $1-2 \mathrm{~mm}$ long, hairs up to $1.5 \mathrm{~mm}$ long. \\
\hline Glume & Upper glume aristate. Lower glume acuminate. & Upper glume and lower glume auricled. \\
\hline Awn & $\begin{array}{l}\text { Awn of the upper lemma } 5-6.2 \mathrm{~cm} \text { long. } \\
\text { Column } 3.0-3.5 \mathrm{~cm} \text { long. Column of the awns } \\
\text { covered with long hairs. }\end{array}$ & $\begin{array}{l}\text { Awn of the upper lemma } 2.2-3.0 \mathrm{~cm} \text { long. } \\
\text { Column } 1.0-1.2 \mathrm{~cm} \text { long. Column of the awns } \\
\text { covered with short bristles. }\end{array}$ \\
\hline $\begin{array}{l}\text { Lower } \\
\text { lemma }\end{array}$ & Distinctly keeled with acuminate apex. & Not keeled with acute apex. \\
\hline Anther & Vinaceous, up to $3 \mathrm{~mm}$ long. & Pale yellow-red, up to $1.5 \mathrm{~mm}$ long. \\
\hline Grain & Yellowish brown, up to $3.5 \mathrm{~mm}$. & Greyish brown up to $2.5 \mathrm{~mm}$. \\
\hline
\end{tabular}

Distribution:-

Dimeria kalliadense is distributed along the wet, marshy areas around the seasonal pools in the lateritic plateaus of Kannur and Kasaragod Districts of Kerala, India.

\section{Acknowledgments:-}

The authors are indebted to the Principal, St. Thomas College, Pala, Kerala for providing necessary laboratory facilities for the work. The first author is grateful to the Principal, Govt. College, Kasargod, Kerala for providing necessary support for the work. The first and second authors are thankful to University Grants Commission for providing financial support as UGC-FIP. The authors are indebted to Mr. Girish Mohan P. K, H. S. A., Govt. Higher Secondary School, Irikkur, Kerala for the support during the field visit.

\section{References:-}

1. Almeida, M. R. (1970): Three new grasses from the former Bombay Presidency. J. Bombay Nat. Hist. Soc., 66: 510-513.

2. Bentham, G. (1846): Prodromus Systematis Naturalis Regni Vegetabilis Vol10. Sumptibus Sociorum Treuttelet Würtz, Parisii, pp. 504. http://dx.doi.org/10.5962/bhl.title.286

3. Brown, R. (1810): Prodromus Florae Novae Hollandiae et Insulae van-Diemen Vol. 1. J. Johnson, London, pp. 204. http://dx.doi.org/10.5962/bhl.title.3678

4. Gamble, J. S. (1924): Flora of the Presidency of Madras Vol. 2.Adlard\& Son, London, pp. 971.

5. Gosavi, K. V. C., Kamble, M. Y., Chandore, A. N. and Yadav, S. R. ( 2016): A new species of Dimeria (Poaceae) from Andaman and Nicobar Islands, India. Phytotaxa, 270 (4): 295-300.

6. Hackel, E. (1889): Monographiae Phanerogamarum(A.D C \& C. D C) Vol. 6. G.Masson, Paris, pp. 78. http://dx.doi.org/10.5962/bhl.itle.45961

7. Kellog, E. A. (2015): Tribes and Genera of Panicoideae. In:Kubitzki K, The families and genera of vascular plants . Flowering plants. Monocots. Poaceae. Cham: Springer International. 13: 301-302. 
8. Kiran Raj, M. S. and Sivadasan, M. (2008): A new species of Dimeria R. Br. (Poaceae, Panicoideae, Andropogoneae) from Goa, India. Novon, 18(2): 183-186.

9. Kiran Raj, M. S., Sivadasan M., Veldkamp J. F., Alfarhan A. H. and Jacob Thomas. (2013): Dimeria gen. nov., subtribe Dimeriinae (Poaceae - Panicoideae -Andropogoneae) from India. Nordic J. Bot., 31: 16-165.

10. Kiran Raj, M. S., Sivadasan, M., Veldkamp, J. F., Alfarhan, A. H. and Amal Thamimi, A. S. M. (2015): A revised intrageneric classification of Dimeria R. Br. (Poaceae: Andropogoneae). Bangladesh J. Plant Taxon., 22(1): 47-54.

11. Kiran Raj, M. S., Sivadasan, M., Dileep, P. and Alfarhan, A. H. (2016.): A new subspecies of Dimeria hohenackeri Hochst. Ex Miq. (Poaceae) from India. Bangladesh J. Plant Taxon., 23(1): 27-31.

12. Mabberley, D. L. (2017) Mabberley's Plant-book.4th ed. Cambridge University Press. Cambridge, UK, XVIII + $1102 \mathrm{p}$.

13. Nair, N. C., Sreekumar, P. V. and Nair, V. J. (1984): Dimeria keralae (Poaceae) - a novelty from Kerala, India. J. Bombay Nat. Hist. Soc., 80: 626-629.

14. Soreng, R. J., Peterson, P. M., Romaschenko, K., Davidse, G., Zuloaga, F. O., Judziewicz, E. J., Filgueiras, T. S., Davis, J. I. and Morrone, O. (2015): A worldwide phylogenetic classification of the Poaceae (Gramineae). Journal of Systematics and Evolution, 53: 117-137.

15. Steudel, E. G. (1855): Synopsis PlantarumGlumacearum II. Cyperaceae. J.B. Metzler, Stuttgartiae, pp. 148. http://dx.doi.org/10.5962/bhl.title.471 